\title{
23. MAJOR-ELEMENT CHEMISTRY OF BASALTIC GLASSES IN HOLE 418A LAVAS AND A DYKE: DEEP SEA DRILLING PROJECT LEGS 52 AND 53
}

\author{
R.N. Thompson, Imperial College of Science and Technology, London, England
}

\section{INTRODUCTION AND ANALYTICAL METHOD}

The fresh glass in quenched samples of ocean-floor basalt provides a means of studying the chemistry of these rocks which eliminates the effects of phenocryst accumulation and subsequent weathering or hydrothermal metamorphism. The results of several investigations using electron-probe microanalyses of these glasses have been published (e.g., Frey et al., 1974; Melson et al., 1976; Bryan and Moore, 1977; Byerly et al., 1977). Byerly and Sinton (this volume) conducted a comprehensive microprobe study of basaltic glasses recovered from Holes 417D and 418A. The work reported here concentrates on a much smaller number of specimens from Hole 418A.

Out of 41 samples examined, 18 yielded glass suitable for analysis. The glasses were studied in polished, thin sections rather than chip mounts. Although sections intersecting fresh glass are often difficult to prepare, they enable unambiguous determination of whether the glass area chosen for microprobe analysis is totally devoid of incipient devitrification.

The analyses were made using the microprobe built by $\mathrm{J}$. V. P. Long at the Department of Mineralogy and Petrology, Cambridge University. This instrument is fitted with an energy-dispersive detector, in contrast to the wavelengthdispersive systems used in the three laboratories (Smithsonian, USGS, and MIT) which have produced most of the analytical data on ocean-floor basalt glasses to date (Melson et al., 1976). The operating conditions were as follows: accelerating voltage $=20 \mathrm{kv}$, specimen current $=0.3 \mu \mathrm{A}$, counting time $=80 \mathrm{~s}$, electron beam focused to its minimum spot. The accuracy of the results was assessed by analysis of an ocean-floor basalt glass (USNM 113716) of known composition, supplied by the Smithsonian Institution. The EDS/DIY Cambridge microprobe analysis of this glass agrees closely with wet-chemistry data for all major elements (see Table 1 and Staudigel, this volume). The largest divergence is for $\mathrm{MgO}(0.28 \%)$; this may be attributed partly to the sparse olivine phenocrysts in the USNM 113716 glass sample. The weakness of energy-dispersive systems lies in their lower sensitivity to elements at low abundances than may be obtained with crystal spectrometers. Thus, no usable data could be measured for $\mathrm{K}_{2} \mathrm{O}$ and $\mathrm{P}_{2} \mathrm{O}_{5}$ in USNM 113716 (Table 1).

\section{RESULTS}

The fresh glass in each thin section is extremely homogeneous, except within a few microns of phenocrysts. The specimens were analyzed in random order. Five analyses were made of each glass and the means of these are listed in Table 2. The stratigraphic coverage of the analyses is variable. Between 510 and 600 meters sub-bottom, it is adequate to represent the recovered material (pillow basalts). The glass analyses in this depth range fall into two clear-cut units. A group that is richer in $\mathrm{MgO}, \mathrm{CaO}$, and $\mathrm{Al}_{2} \mathrm{O}_{3}$ and poorer in $\mathrm{FeO}$ and $\mathrm{TiO}_{2}$ occurs between 510 and 529 meters. Another group, richer in $\mathrm{FeO}$ and $\mathrm{TiO}_{2}$ and poorer in $\mathrm{MgO}, \mathrm{CaO}$, and $\mathrm{Al}_{2} \mathrm{O}_{3}$, occurs between 538 and 589 meters. The means and standard deviations $(2 \sigma)$ of these groups are given in Table 1 . To facilitate comparison with Smithsonian data, the individual analyses were recalculated to 100 per cent before the group means were computed. In contrast with Smithsonian procedure (Melson et al., 1976), the analyses were not normalized to the composition of a basalt-glass internal standard. It is apparent from Table 1 that these stratigraphic glass groups, representing core lengths of 19 and 51 meters, are as homogeneous as the standard glass sample USNM 113716. Presumably, they represent two eruptive units.

Byerly and Sinton (this volume) have divided their glass analyses from the 510- to 603-meter section of Hole 418A into the following three stratigraphic groups: C (510 to 529 $\mathrm{m}), \mathrm{D}(531$ to $567 \mathrm{~m})$, and $\mathrm{E}$ (568 to $603 \mathrm{~m})$. Group C corresponds with the most magnesian group in Table 1 . Comparison between my data for Group $\mathrm{C}$ and that of Byerly and Sinton (this volume) shows small differences for all elements. The largest divergence is 0.25 per cent for $\mathrm{CaO}$. Similar and slightly larger differences are recorded by Melson et al. (1976, Table 1) in their comparison of MIT and Smithsonian microprobe analyses of five ocean-floor basalt glasses.

The chemical differences between glass-stratigraphic groups D and E of Byerly and Sinton (this volume) are small; for all elements, they are much less than the pub-

TABLE 1

Average Analyses of Basalt Glasses From Hole 418A

\begin{tabular}{|c|c|c|c|c|c|c|c|c|}
\hline \multirow{2}{*}{$\begin{array}{l}\text { Sub-Bottom Depth } \\
\text { Interval (m) } \\
\text { No. of analyses }\end{array}$} & \multicolumn{2}{|c|}{$510-529$} & \multicolumn{2}{|c|}{$538-589$} & \multicolumn{2}{|c|}{$>638$} & \multicolumn{2}{|c|}{ (USNM 113716) } \\
\hline & 3 & & 10 & & 5 & & $(10 \mathrm{pc}$ & ints) \\
\hline & & $2 \underline{a}$ & & $2 \underline{g}$ & & $2 \underline{a}$ & & $2 \underline{g}$ \\
\hline $\mathrm{SiO}_{2}$ & 50.40 & 0.20 & 50.57 & 0.16 & 51.10 & 0.27 & 51.71 & 0.61 \\
\hline $\mathrm{Al}_{2} \mathrm{O}_{3}$ & 15.68 & 0.08 & 15.44 & 0.14 & 14.26 & 0.23 & 15.58 & 0.30 \\
\hline $\mathrm{Cr}_{2} \mathrm{O}_{3}$ & 0.10 & 0.09 & 0.07 & 0.05 & 0.03 & 0.04 & 0.06 & 0.15 \\
\hline $\mathrm{FeO}$ & 9.66 & 0.08 & 10.13 & 0.18 & 11.28 & 0.37 & 9.04 & 0.17 \\
\hline $\mathrm{MnO}$ & 0.14 & 0.04 & 0.14 & 0.06 & 0.14 & 0.04 & 0.14 & 0.04 \\
\hline $\mathrm{MgO}$ & 8.45 & 0.01 & 8.12 & 0.08 & 7.19 & 0.11 & 7.93 & 0.34 \\
\hline $\mathrm{NiO}$ & - & - & - & - & - & - & 0.02 & 0.10 \\
\hline $\mathrm{CaO}$ & 12.36 & 0.18 & 12.15 & 0.08 & 11.67 & 0.10 & 11.18 & 0.27 \\
\hline $\mathrm{Na}_{2} \mathrm{O}$ & 2.20 & 0.10 & 2.20 & 0.14 & 2.34 & 0.16 & 2.61 & 0.24 \\
\hline $\mathrm{K}_{2} \mathrm{O}$ & - & - & - & - & 0.03 & 0.02 & 0.01 & 0.07 \\
\hline $\mathrm{TiO}_{2}$ & 1.02 & 0.08 & 1.18 & 0.06 & 1.54 & 0.12 & 1.32 & 0.13 \\
\hline $\mathrm{P}_{2} \mathrm{O}_{5}$ & - & - & tr & - & tr & - & - & - \\
\hline Total & 100.01 & & 99.99 & & 99.58 & & 99.60 & \\
\hline
\end{tabular}


TABLE 2

Microprobe Analyses of Basalt Glasses in Lavas and a Dyke From Hole 418A

\begin{tabular}{|c|c|c|c|c|c|c|c|c|c|c|c|c|c|c|c|c|c|c|}
\hline $\begin{array}{c}\text { Sample } \\
\text { (Interval in } \mathrm{cm} \text { ) }\end{array}$ & $\begin{array}{l}42-3 \\
11-15\end{array}$ & $\begin{array}{l}42-4 \\
9-12\end{array}$ & $\begin{array}{l}44-3 \\
29-32\end{array}$ & $\begin{array}{l}45-3 \\
95-99\end{array}$ & $\begin{array}{l}46-1 \\
25-30\end{array}$ & $\begin{array}{c}46-3, \\
128-134\end{array}$ & $\begin{array}{l}47-2 \\
93-98\end{array}$ & $\begin{array}{l}48-1 \\
125-129\end{array}$ & $\begin{array}{l}48-4 \\
21-24\end{array}$ & $\begin{array}{l}49-1 \\
135-139\end{array}$ & $\begin{array}{l}50-5 \\
47-50\end{array}$ & $\begin{array}{c}51-3, \\
122-126\end{array}$ & $\begin{array}{l}51-5 \\
21-26\end{array}$ & $\begin{array}{l}56-7 \\
69-74\end{array}$ & $\begin{array}{l}69-1, \\
134-140\end{array}$ & $\begin{array}{r}73-3 \\
2-9\end{array}$ & $\begin{array}{l}74-1 \\
9-12\end{array}$ & $\begin{array}{c}79-3 \\
115\end{array}$ \\
\hline $\begin{array}{l}\text { Sub-Bottom } \\
\text { Depth }(m)\end{array}$ & 511 & 512 & 529 & 539 & $\$ 44$ & 548 & 555 & 563 & 566 & 572 & 580 & 587 & 589 & 638 & 735 & 766 & 774 & 816 \\
\hline $\mathrm{SiO}_{2}$ & 50.20 & 50.28 & 50.18 & 50.57 & 50.57 & 50.36 & 50.45 & 50.29 & 50.47 & 50.56 & 50.39 & 50.26 & 50.19 & 50.95 & 50.95 & 51.22 & 51.16 & $\$ 1.20$ \\
\hline $\mathrm{Al}_{2} \mathrm{O}_{3}$ & 15.64 & 15.66 & 15.56 & 15.49 & 15.50 & 15.39 & 15.56 & 15.33 & 15.45 & 15.44 & 15.35 & 15.19 & 15.26 & 14.45 & 14.22 & 14.24 & 14.27 & 14.13 \\
\hline $\mathrm{Cr}_{2} \mathrm{O}_{3}$ & 0.15 & 0.09 & 0.06 & 0.05 & 0.05 & 0.08 & 0.11 & 0.05 & 0.05 & 0.10 & 0.07 & 0.04 & 0.10 & 0.02 & 0.03 & - & 0.02 & 0.06 \\
\hline $\mathrm{FeO}$ & 9.68 & 9.58 & 9.62 & 9.98 & 10.03 & 10.05 & 10.06 & 10.13 & 10.11 & 10.19 & 10.23 & 10.09 & 10.15 & 11.52 & 11.33 & 11.18 & 11.03 & 11.36 \\
\hline $\mathrm{MnO}$ & 0.13 & 0.12 & 0.16 & 0.09 & 0.17 & 0.15 & 0.16 & 0.10 & 0.13 & 0.19 & 0.12 & 0.15 & 0.14 & 0.12 & 0.14 & 0.15 & 0.12 & 0.16 \\
\hline $\mathrm{MgO}$ & 8.44 & 8.42 & 8.40 & 8.16 & 8.10 & 8.13 & 8.17 & 8.04 & 8.15 & 8.05 & 8.12 & 8.04 & 8.02 & 7.23 & 7.12 & 7.20 & 7.25 & 7.15 \\
\hline $\mathrm{NiO}$ & - & - & - & - & - & - & - & - & - & - & - & 0.03 & - & - & - & - & - & - \\
\hline $\mathrm{CaO}$ & 12.28 & 12.27 & 12.40 & 12.14 & 12.12 & 12.18 & 12.14 & 12.04 & 12.06 & 12.15 & 12.13 & 12.05 & 12.06 & 11.73 & 11.63 & 11.70 & 11.61 & 11.67 \\
\hline $\mathrm{Na}_{2} \mathrm{O}$ & 2.26 & 2.18 & 2.15 & 2.14 & 2.24 & 2.22 & 2.23 & 2.23 & 2.25 & 2.03 & 2.15 & 2.22 & 2.20 & 2.41 & 2.30 & 2.27 & 2.44 & 2.28 \\
\hline $\mathrm{K}_{2} \mathrm{O}$ & - & - & - & - & - & - & - & - & 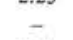 & - & - & - & - & 0.03 & 0.02 & 0.04 & 0.03 & 0.02 \\
\hline $\mathrm{TiO}_{2}$ & 1.06 & 1.01 & 0.98 & 1.16 & 1.16 & 1.17 & 1.19 & 1.20 & 1.21 & 1.19 & 1.14 & 1.22 & 1.11 & 1.64 & 1.55 & 1.48 & 1.51 & 1.52 \\
\hline $\mathrm{P}_{2} \mathrm{O}_{5}$ & - & - & - & - & 0.04 & - & - & - & - & - & - & - & - & - & - & - & 0.03 & - \\
\hline Total & 99.84 & 99.61 & 99.51 & 99.78 & 99.98 & 99.73 & 100.07 & 99.41 & 99.88 & 99.78 & 99.70 & 99.29 & 99.23 & 100.10 & 99.29 & 99.48 & 99.47 . & 99.55 \\
\hline
\end{tabular}

lished $2 \sigma$ precision of replicate analyses of the Smithsonian basalt-glass internal standard VG-2 (Byerly et al., 1977; their table 8). Selected elements in the glasses from the 530 to 600 -meter interval of Hole $418 \mathrm{~A}$ analyzed by the author are plotted in Figure 1. No discontinuity is apparent in the chemical stratigraphy of these glasses, either at 568 meters (the depth chosen by Byerly and Sinton) or at any other point in the 530-to 600-meter interval. At first glance, there are signs of progressive stratigraphic variation in the abundances of certain oxides, such as the upward decrease of $\mathrm{TiO}_{2}$ between 567 and 538 meters. When comparison is made, however, with the $2 \sigma$ precision of the author's replicate analyses of the basaltic standard glass USNM 113716 (Figure 1), these chemical trends clearly cannot be regarded as significant.

Chemical analyses of most of the rocks containing the glasses included in this study are reported by Flower et al. (this volume). The rock major-element data for the 530 to 600 -meter interval of Hole $418 \mathrm{~A}$ are plotted on Figure 1. It is apparent that they differ considerably from their equivalent glasses and are much more variable than the latter. A similar relationship has been noted by Byerly et al. (1977, their fig. 1) for a 70-meter interval at Site 238, Leg 24. Relative to the analyses of the rocks containing them, the Hole 418A glasses are all enriched in $\mathrm{SiO}_{2}$, total $\mathrm{Fe}, \mathrm{MgO}$, and $\mathrm{TiO}_{2}$ and are impoverished in $\mathrm{Al}_{2} \mathrm{O}_{3}$ and $\mathrm{CaO}$. Byerly et al. (1977) stress the role of metasomatic processes (during the crystallization of ocean-floor basalt and subsequent alteration by circulating hydrothermal fluids) in producing the chemical differences between rock and glass analyses of samples. These authors state that most of the lavas studied by them are only sparsely phyric ( $<5 \%$ phenocrysts). In contrast, the Hole $418 \mathrm{~A}$ basalts have variable phenocryst contents in excess of 10 per cent; consisting of dominant plagioclase, small amounts of olivine throughout, clinopyroxene at some horizons, and occasional trace amounts of $\mathrm{Cr}-\mathrm{Al}$ spinel. The rock-glass chemical relationship shown in Figure 1 suggests that variable accumulation of plagioclase phenocrysts may be a major cause of the differences between rock and glass compositions.

The five glasses analyzed by the author from Hole $418 \mathrm{~A}$ cores below 600 meters are all richer in $\mathrm{SiO}_{2}, \mathrm{FeO}$, and $\mathrm{TiO}_{2}$, and poorer in $\mathrm{Al}_{2} \mathrm{O}_{3}, \mathrm{MgO}$, and $\mathrm{CaO}$ than those from higher stratigraphic levels. The mean of these analyses, including the chilled margin of a dyke (Sample 418A-79-3, $115 \mathrm{~cm}$ ), is given in Table 1. Although this Ti-rich group is as homogeneous chemically as the replicate analyses of USNM 113716, it is clear from the more extensive data of Byerly and Sinton (this volume) that the lavas and dykes in the lower part of Hole 418A may be divided into several discrete chemical groups. All of these are richer in $\mathrm{TiO}_{2}$ than the lavas above 600 meters.

\section{DISCUSSION}

Perhaps the most obvious problem raised by this study is the extent to which microprobe analyses of basaltic glasses made by various laboratories may be compared. Comparison of the author's data with those of Byerly and Sinton (this volume) suggests that the combined results of several laboratories may be used successfully to sub-divide a section of ocean-crust lavas (such as the section drilled in Hole $418 \mathrm{~A}$ ) into its major chemical/stratigraphic units. The more subtle chemical divisions, however, are likely to be recognized only within the data set of a single laboratory.

The validity of very fine chemostratigraphic divisions based on glasses from DSDP holes has implications for ocean-floor volcanology. If the pillow basalts in the 530-to 600 -meter interval of Hole 418A form a single eruptive unit of homogeneous liquid composition, this would suggest that basalt eruptive units drilled in the ocean floor are sometimes comparable in thickness to the topographic relief of Mt. de Venus and Mt. Pluto in the FAMOUS area. There is a general resemblance between these and monogenetic, compound-flow volcanoes of the Skjaldbreidur type in Iceland (Walker, 1971). If, on the other hand, Byerly and Sinton (this volume) are correct in sub-dividing the Hole $418 \mathrm{~A}$ glasses chemically at 568 meters, this would reinforce the suggestion made in several previous Initial Reports that the eruptive units forming the upper oceanic crust are all comparatively thin ( $\sim 8$ to $10 \mathrm{~m})$.

The chemical relationship between the three compositional types of Hole 418A glasses listed in Table 1 will not be discussed in detail in this article because the author lacks the trace-element data necessary to test conclusions based upon major elements. The chemical trend shown by the glass groups (Table 1) can be related qualitatively to fractional crystallization of olivine, plagioclase, Cr-spinel, and/or Ca-rich clinopyroxene. It is, of course, necessary 


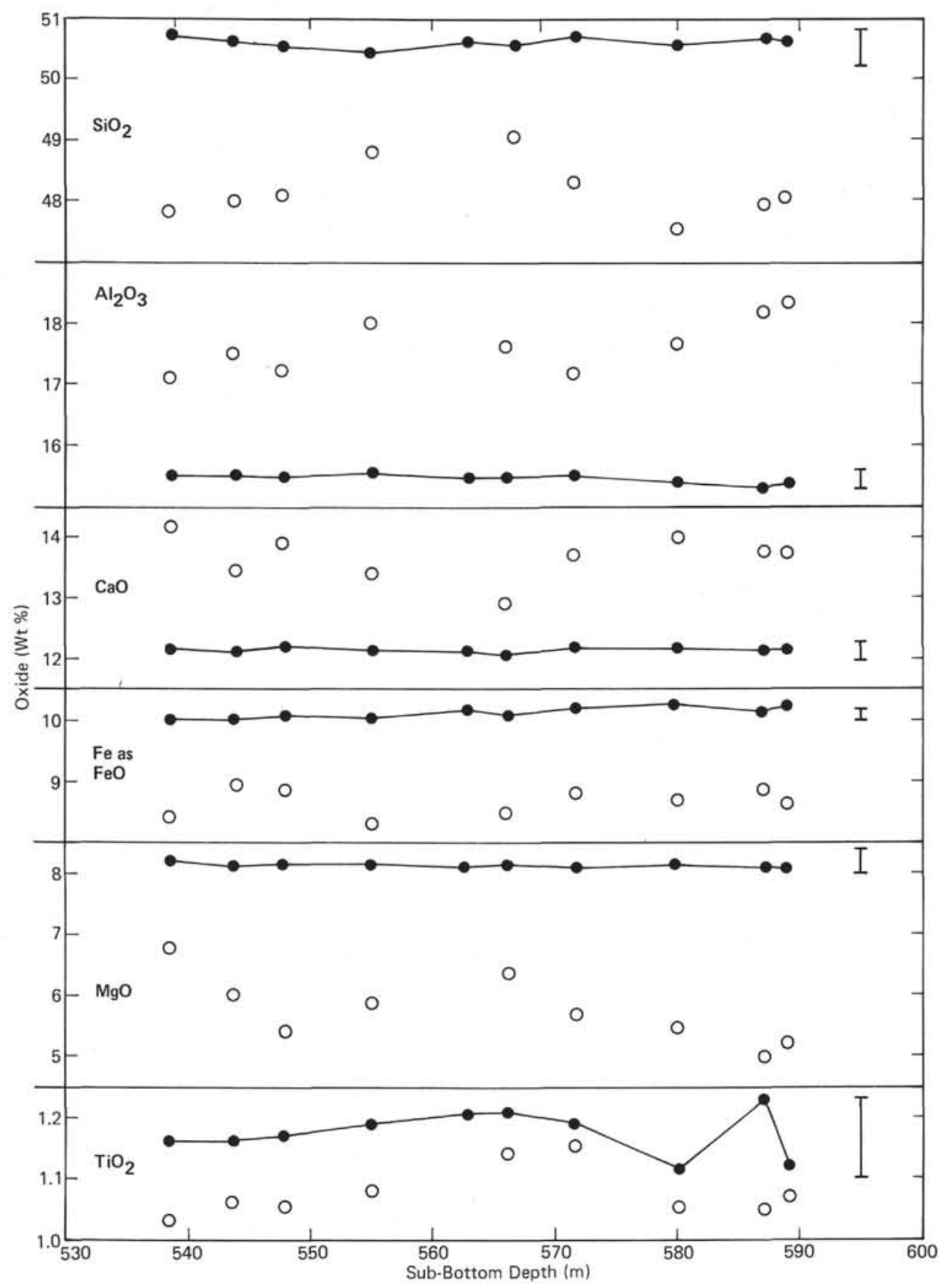

Figure 1. Chemical variation in basalts from the 530- to 600-meter sub-bottom depth interval of Hole 418A. Key to symbols: $\bigcirc=$ lavas, $\bullet=$ glasses contained in lavas. The error bars are for the precision (2o) of replicate analyses of standard glass USNM 113716.

first to determine the compositions of the liquidus phases precipitating from each group before a quantitative model can be constructed. This normally routine step presents considerable difficulties in the Hole $418 \mathrm{~A}$ basalts, as will be illustrated here by a summary of the phenocryst mineralogy of lavas in the 530- to 600-meter interval.

Olivine phenocrysts in the samples plotted in Figure 1 are euhedral and vary in composition from Fo8s to Fo82. Plagioclase megacrysts with euhedral, skeletal, and rounded or embayed morphologies coexist in most sections. The euhedral crystal core compositions range from An86 to $\mathrm{An}_{78}$. In some samples, the rounded plagioclase megacrysts are more calcic than their euhedral neighbors (e.g., $\mathrm{An}_{93}$ in Sample 418A-49-1, 135-139 cm) while they are more sodic in others (e.g., An 70 in Sample 418A-45-3, 95-99 cm). Ca-rich clinopyroxene megacrysts $\left[\mathrm{Mg} /\left(\mathrm{Mg}+\mathrm{Fe}^{+2}\right)\right.$ $<0.85$ ] occur sporadically in lavas from the 530- to 600 meter section and show varying degrees of rounding and 


\section{R. N. THOMPSON}

embayment. A few samples contain euhedral $\mathrm{Cr}$-Al-rich spinel microphenocrysts $[\mathrm{Mg} /(\mathrm{Mg}+\mathrm{Fe})<0.60]$. Clearly, until the compositional diversity of the plagioclase megacrysts and the rounding and embayment of the clinopyroxenes are fully understood, there can be no progress in reconstructing the genetic relationships of these lavas.

\section{ACKNOWLEDGMENTS}

M. F. J. Flower kindly provided the glass samples used in this study, together with chemical analyses of the lavas containing them. J. V. P. Long permitted use of the Cambridge University microprobe and N. J. Charnley gave instruction and assistance in its operation. E. Jarosewich supplied a sample of the standard basalt glass USNM 113716. The manuscript has benefited from critical reviews by I. L. Gibson and M. A. Morrison. The author's work on ocean-floor lavas is supported by Natural Environment Research Council Grant GR3/2946.

\section{REFERENCES}

Bryan, W.B. and Moore, J.G., 1977. Compositional variations of young basalts in the Mid-Atlantic Ridge rift valley near lat $36^{\circ} 49^{\prime}$ N, Geol. Soc. Am. Bull., v. 88, p. 556-570.

Byerly, G.R., Melson, W.G., Nelen, J.A., and Jarosewich, E., 1977. Abyssal basaltic glasses as indicators of magma compositions, Smithsonian Contrib. Earth Sci., no. 19, p. 22-30.

Frey, F.A., Bryan, W.B., and Thompson, G., 1974. Geochemistry and petrology of basalts from Legs 2 and 3 of the Deep-Sea Drilling Project, J. Geophys. Res., v. 79, p. 5507-5527.

Melson, W.G., Vallier, T.L., Wright, T.L., Byerly, G., and Nelen, J., 1976. Chemical diversity of abyssal volcanic glass erupted along Pacific, Atlantic, and Indian Ocean sea-floor spreading centers, Am. Geophys. Union, Mono. 19, p. 351-368.

Walker, G.P.L., 1971. Compound and simple lava flows and flood basalts, Bull. Volc., v. 35 , p. $579-590$. 